\title{
DEVELOPMENT OF MICROBIOLOGICAL CULTURE MEDIUM BASED ON PROTEIN HYDROLYSATE OBTAINED THROUGH ELECTROCHEMICAL METHOD FROM PROTEIN WASTE
}

\author{
S.V.Vodolazhskay, \\ Saint-Petersburg State Institute of Technology, Russia \\ H.E.Kuprina \\ State Institute of Fish Industry "Giproribflot", Russia \\ G.G.Nyanikova \\ Saint-Petersburg State Institute of Technology, Russia
}

Keywords: protein-containing waste, electrochemical technology, protein hydrolysate, microbiological culture media

\section{Introduction.}

The preparation protein products is the impotent direction of reprocessing invaluable fish and other hydrocoles and their waste. Waste-free utilization of these resources assumes the complete recovery of meat used for the food purposes, obtaining the protein hydrolysates from the protein-containing waste and using the insoluble residue for manufacture of fodder flour. Protein hydrolysates are highly nutritious products. Properties of protein hydrolysates depend on initial raw material and methods of their obtaining. Protein hydrolysates have the greatest distribution for manufacture of broth concentrates, sauces and on the fodder purposes. But volume of consumption in the listed areas is rather limited. Using hydrocoles waste hydrolysates as bases of microbiological culture media for production and diagnosing of microorganisms in microbiological industry, medicine, veterinary science is the most advanced $/ 5 /$.

\section{Results and discussion.}

It is known, that the common methods of protein hydrolysates obtaining from hydrocoles are chemical and biological.

The concentrated hydrochloric acid is used for obtaining protein hydrolysates from raw material or protein-containing waste $/ 2$. Acid hydrolysis allows to produce rather standard 
hydrolysates with high degree of protein-splitting. Enzyme hydrolysis provides for partial protein splitting at the expense of added enzymes $/ 3,4 /$. But, in spite of a plenty of studies on processing fish and crustaceans waste through acid and enzyme hydrolysis the problem of recycling these waste is still urgent. The huge amount of crab shell has accumulated on the Pacific coast of Russia, annually in England at the processing of the Norwegian lobster collects up to 12 thousand tons of protein and chitin containing wasted $1 /$.

The point is that acid and enzyme hydrolysis used for reprocessing waste have a number of disadvantages limiting their application.

Disadvantages of an acid hydrolysis:

- The necessity to use strong concentrated acids $(6 \mathrm{n} \mathrm{HCl}, \mathrm{t}=100-250 \stackrel{\circ}{\circ})$, substantially makes worse the ecology of such manufacture.

- The necessity for neutralization and removal a plenty of salts.

- The large discharge of fresh water.

- The partial destruction of some amino acids: serine, threonine, cysteine, tyrosine, the most part of tryptophan.

- Formation ofehumic substances, which is difficult to remove.

Disadvantages of an enzyme hydrolysis:

- A low degree of protein extraction from waste.

- The expensiveness because of using pure enzymes.

- Nonstandard.

- Presence of significant amount of contominants.

- A long time of hydrolysis.

- The necessity to maintain sterility.

The electrochemical technology of hydrocole conversion, which was worked out in the State Institute of Fish Industry (St-Petersburg, Russia), allows to obtain protein hydrolysates, chitin, chitosan and lipides in one technological line. The electrochemical method of protein dissolving allows to combine the high quality of obtained product (protein hydrolysate) and the highest level of protein extraction. It is achieved when $\mathrm{pH}$, direct electrical current and red-ox potential affect protein containing waste simultaneously.

The modified electrochemical technology, which allows to increase the degree of proteinsplitting, was developed for obtaining protein hydrolysates - bases of microbiological culture media. Additional reagents and units of equipment were not used. Optimal electrochemical operating conditions were studied. The offered technology can be used for processing both pure protein waste and chitin-containing waste of crustaceans. Fig. 1

The offered electrochemical method of hydrolysis in comparison with acid and enzyme ones has the following advantages:

1. It does not require using of acids and alkalis, hydrolysis of protein and neutralization are carried out in electrolyzer under mild conditions, that prevents destruction of amino acids.

2. Decrease of units of equipment.

3. There is an opportunity to change of a technological line. It allows to obtain protein hydrolysates from various protein-containing waste: soy, sunflower, fish and meat waste, crustaceans, whey, by-products of microbiological manufactures.

4. Protein hydrolysates have a long time shelf-life. It was shown, that liquid hydrolysate $\mathrm{pH}=7.4, \mathrm{t}=0-8{ }^{\circ} \mathrm{C}$ can be stored no more than 12 days. Liquid hydrolysate $\mathrm{pH}=12.3, \mathrm{t}=18$ $20^{\circ} \mathrm{C}$ can be stored no less than 60 days. General bacterial seeding was studied by method of limited dilutions (Koch method). Tab.1 


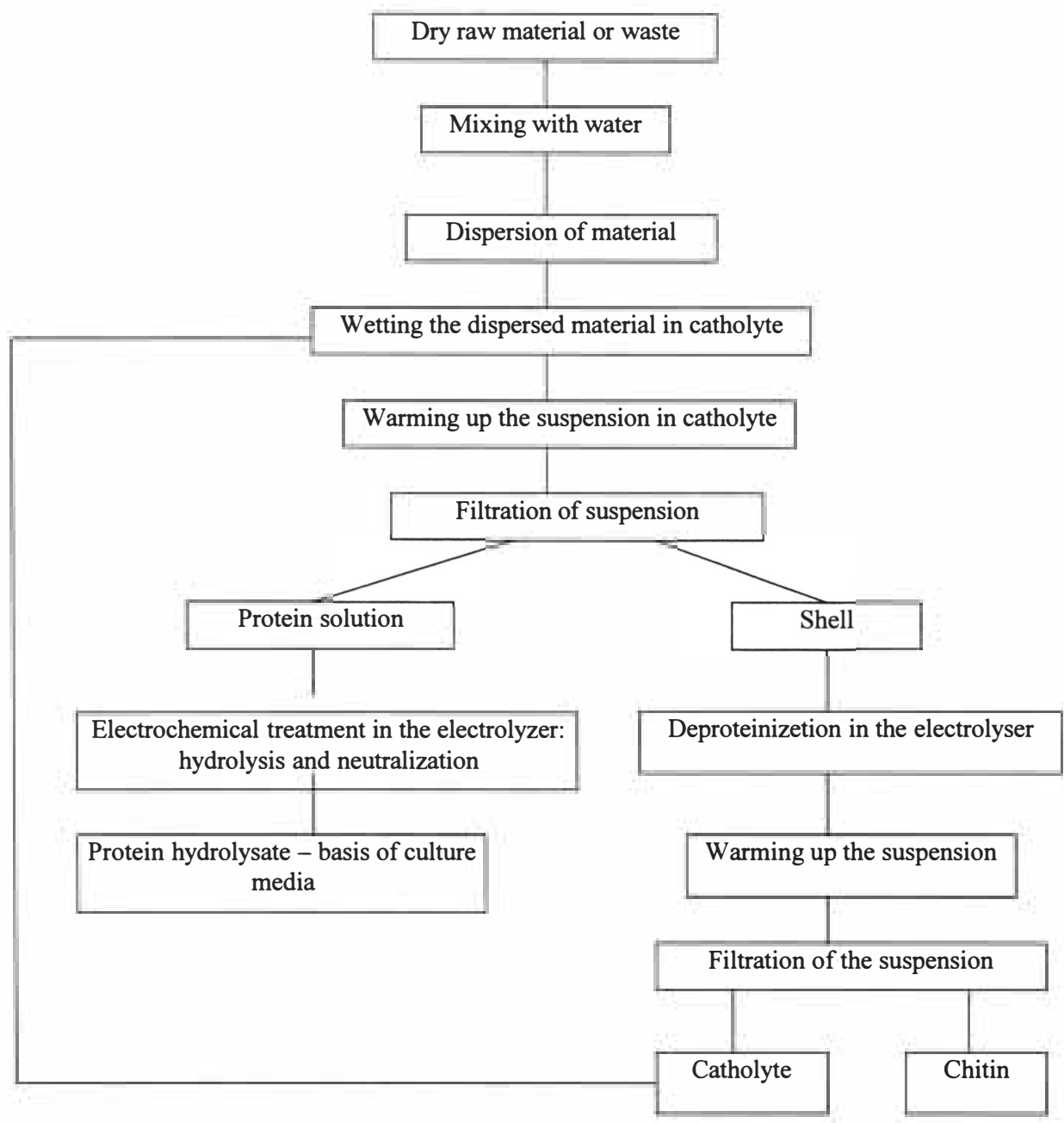

Fig.1

Technological scheme of obtaining protein hydrolysates - bases of culture media and chitin through electrochemical method

Effect of $\mathrm{pH}$, temperature, and storage time on general bacterial seeding of protein hydrolysates from Gammarus pulex 
Table 1.

\begin{tabular}{|c|c|c|c|c|}
\hline \multicolumn{5}{|c|}{ Mesophilous aerobe and facultative anaerobe microorganisms, sell numbers/g } \\
\hline \multirow[t]{2}{*}{$\begin{array}{c}\text { Storage time, } \\
\text { days }\end{array}$} & \multicolumn{2}{|c|}{$\begin{array}{c}\text { Protein hydrolysate } \\
\mathrm{pH} 7,0\end{array}$} & \multicolumn{2}{|c|}{$\begin{array}{c}\text { Protein hydrolysate } \\
\mathrm{pH} 12,3\end{array}$} \\
\hline & $t=18-20 \mathrm{eC}$ & $\mathrm{t}=0-8 \mathrm{e} \mathrm{C}$ & $t=18-20 \mathrm{eC}$ & $\mathrm{t}=0-8^{\mathrm{O}} \mathrm{C}$ \\
\hline 0 & \multicolumn{2}{|c|}{$3,0 \times 10^{2}$} & \multicolumn{2}{|c|}{ Individual cells } \\
\hline 1 & $1,6 \times 10^{4}$ & $5,2 \times 10^{2}$ & Indiv. cells & Indiv. Cells \\
\hline 2 & $3,5 \times 10^{4}$ & $2,1 \times 10^{3}$ & 0 & 0 \\
\hline 3 & $5,0 \times 10^{5}$ & $2,5 \times 10^{2}$ & Indiv. cells & Indiv. cells \\
\hline 5 & $2,0 \times 10^{7}$ & $4,0 \times 10^{2}$ & Indiv. cells & Indiv. cells \\
\hline 6 & $9,5 \times 10^{7}$ & $2,0 \times 10^{3}$ & Indiv. cells & 0 \\
\hline 7 & --- & $2,0 \times 10^{3}$ & 0 & Indiv. cells \\
\hline 9 & --- & $2,0 \times 10^{3}$ & Indiv. cells & Indiv. cells \\
\hline 12 & --- & $2,0 \times 10^{3}$ & Indiv. cells & 0 \\
\hline 14 & --- & $1,6 \times 10^{4}$ & 0 & 0 \\
\hline 16 & --- & $1,8 \times 10^{4}$ & Indiv. cells & 0 \\
\hline 29 & --- & --- & $1,9 \times 10^{3}$ & 0 \\
\hline 33 & --- & --- & $2,2 \times 10^{4}$ & 0 \\
\hline 34 & --- & --- & $1,1 \times 10^{5}$ & 0 \\
\hline 35 & --- & --- & $1,2 \times 10^{6}$ & 0 \\
\hline 37 & --- & --- & -- & Indiv. Cells \\
\hline 44 & --- & --- & --- & Indiv. Cells \\
\hline 60 & --- & --- & -- & $1,0 \times 10^{1}$ \\
\hline
\end{tabular}

Fresh-water crustaceans Gammurus pules is used for obtaining chitin and chitosan through electrochemical method in the enterprise in the town Nara (Russia). It was offered to produce protein hydrolysate - basis of culture media fron protein component which was a waste.

A new industrial culture medium for production cell-mass of bacterium Bacillus mucilaginosus was developed. Bacillus mucilaginosus is a soil microorganism, saprophyte, harmless for people and animals. Bacillus mucilaginosus is a producer of biologically active substances and is used as an environmental rehabilitation agent for improving physicchemical properties of soil and as a fodder in agriculture.

The biochemical characteristic of electrochemical hydrolysate in comparison with enzyme (pancreatic) one was determined. Tab.2. 
The biochemical composition of Gammurus pulex hydrolysate

Table 2.

\begin{tabular}{|l|c|c|}
\hline Parameters & Electrochemical hydrolysate & Enzyme hydrolysate \\
\hline Amine nitrogen, \% dry & 2.8 & 6.9 \\
\hline Total nitrogen, \% dry & 9.6 & 10.6 \\
\hline Degree of protein splitting,\% & 29 & 30 \\
\hline Protein, \% dry & 60 & 66 \\
\hline $\mathrm{NaCl} \%$ dry & 19.3 & 15.6 \\
\hline $\mathrm{NaCl} \%$ liquid & 1.2 & 1.0 \\
\hline Lipides, \% dry & 3.7 & 1.9 \\
\hline Ashes, \% & 22.7 & 18.2 \\
\hline
\end{tabular}

Amine nitrogen was determined by Formolin titration, total nitrogen - by Kjeldahl method, lipides - by Folch method, $\mathrm{NaCl}$ - by argentometry titration, ashes - by gravimetric analysis. Element composition of electrochemical hydrolysate was determined by electron-sounding Xray microanalysis: $\mathrm{Na}-9.2 \%, \mathrm{Si}-0.8 \%, \mathrm{P}-0.2 \%, \mathrm{~S}-0.8 \%, \mathrm{~K}-0.8 \%, \mathrm{Ca}-0.9 \%$.

An optimized industrial culture medium based on electrochemical hydrolysate of Gammarus pulex was developed for cell-mass production by Bacillus mucilaginosus. The medium consists of electrochemical hydrolysate of Gammarus pulex - 92-96 \%, malasses - 4-8 \%, $\mathrm{NaCl}-1.0-3.0 \%$. The fermentation was conducted during 24 hours, flask volume $=750 \mathrm{sm}^{3}$, medium volume $=50 \mathrm{sm}^{3}, \mathrm{t}=35^{\circ} \mathrm{C}$, rotation speed $=200$ revolutions per minute.

Cell-mass yields of Bacillus mucilaginosus grown on the media composed of electrochemical protein hydrolysate and enzyme hydrolysate of Gammarus pulex are given in Tab.3.

Cell-mass yield of Bacillus mucilaginosus

Table 3

\begin{tabular}{|l|c|}
\hline Protein basis & Dry cell-mass, $\mathrm{g} / \mathrm{dm}^{3}$ \\
\hline Electrochemical hydrolysate & $8.4-9.6$ \\
\hline Enzyme hydrolysate & $3.1-4.2$ \\
\hline
\end{tabular}

Cell-mass yield of Bacillus mucilaginosus grown on the medium based on electrochemical hydrolysate is 2 times higher than cell-mass grown on the medium based on the enzyme hydrolysate, in spite of electrochemical hydrolysate contains 2.4 times less amine nitrogen than enzyme hydrolysate. Perhaps, combined effect of an electromagnetic field, electrical current and red-ox potential caused changes just not only in biochemical and structural properties, but also improve growth properties.

\section{Conclusion.}

A new electrochemical technology for obtaining protein hydrolysates - bases of microbiological culture media was developed. Biochemical properties of Gammarus pulex protein hydrolysate obtained through electrochemical method from protein-containing waste in chitin production were determined. An optimized industrial culture medium based on electrochemical hydrolysate of Gammarus pulex was developed for cell-mass production by Bacillus mucilaginosus. 


\section{References:}

1. Baxter Alasdair.(1989) The utilization of scampi waste. Food Sci.and Technol. Today. 3. Vol 1. Pp.130-131.

2. Jaswal A.C. (1989) Methodology investigation for the production of amino acid hydrolysate from shrimp waste. Can.inst.food sci and Technol.J.,22,V5.pp.460-465. DOI: https://doi.org/10.1016/50315-5463(89)70597-6

3. New Technologies in Fish Industry.(1989). Development of a new technology for obtaining enzyme protein hydrolysates from fish waste. Report. Vladivastok. Russia.

4. Perebeynas A.B., Kalinichenko T.P..(1995). Enzyme hydrolysis of fish waste in fodder production. Fish Industry. Vol 6,pp.46-48. Russia.

5. Shelepin A.P. Marchihina I.I. (1997). Culture medium for microorganisms production. Patent $2089609 \mathrm{MKI}^{6}$ C 12N 1/20. Russia. 